\title{
Harpacticoida (Copepoda) Fauna and the Taxocene Diversity of the South China Sea
}

\author{
E. S. Chertoprud ${ }^{a}$, S. Gómez ${ }^{b}$, and H. Gheerardyn ${ }^{c}$ \\ ${ }^{a}$ Moscow State University, Moscow, Russia \\ ${ }^{b}$ Institute of Marine Sciences and Limnology, National Autonomous University of Mexico, Mexico \\ ${ }^{c}$ University of Ghent, Ghent, Belgium \\ E-mail: horsax@yandex.ru
}

Received February 27, 2008; in final form, June 11, 2008

\begin{abstract}
The full characterized list of known species of Harpacticoida is presented for the South China Sea based on original and literature data. Three Harpacticoida taxocenes from soft sediments are described on the littoral and sublittoral of shallows of Nha Trang Bay (Vietnam). The first taxocene is represented by dominating species of the genuses Phyllopodopsyllus and Brianola at the upper and middle littorals. The second one, which is characterized by dominating species of the genus Diarthrodes, is found on sublittoral, silty and fine sands. The third taxocene with dominating species of the genus Amphiascoides is described at coarse sands. The sediment type is a main factor of the organization of sublittoral harpacticoids associations. The depth also has an effect on the harpacticoids diversity and abundance. A comparative analysis of the Harpacticoida species composition is presented for the South China Sea, the Philippines, the Malay Archipelago, New Guinea, the Yellow Sea, and the Andaman and Nicobar Islands. The similarity of the species lists of the considered sector of the Indo-Pacific is extremely low. The main reason for the present high specificity of the faunas of the compared regions is the deficit of studies on Harpacticoida in tropical waters.
\end{abstract}

DOI: $10.1134 / \mathrm{S} 0001437009040079$

\section{INTRODUCTION}

The South China Sea is one of the biggest shelf seas in the tropics. It is bordered by Indo-China in the West and by the Greater Sunda Isles and the Philippines from the South and the East. Data on the Harpacticoid fauna are lacking for this area, as well as for the other tropical seas. The stand-alone publications are dedicated to the shallow waters of the Philippines and describe both free-living $[7,15,56]$ and symbiotic species $[17,59]$. Some harpacticoids are known from the China estuaries $[61,62,63]$ and sea waters $[64,69]$. Two species were described for the Vietnamese seacoast [35]. The Thailand estuarian fauna of Harpacticoids is known from old publications combined in Lang's monograph [48]. The plankton species are described more thoroughly $[11,12,40,48,65]$. Data on the ecology of the benthic copepod taxocenes of the South China Sea are almost lacking. The vertical distribution of psammophilous meiobentos was described only for Kalimantan (Borneo) Island, and the harpacticoids were defined only by genus [49].

The aim of the present investigation is to compile a harpacticoid species list using original and literature data for the South China Sea, as well as to describe their taxocenes for the soft sediments in Nha Trang Bay of South Vietnam. As a result, a comparative analysis of the faunas of the South China Sea and the adjacent areas is presented.

\section{MATERIALS AND METHODS}

Original data. Ongoing studies of marine benthic invertebrates have been conducted in Nha Trang Bay for the last 19 years (1990-2008). A database on various substrates (benthic and coral reefs) has been created.

The samples for the present study were taken on the soft sediments in Nha Trang Bay in April-May of 2004. The sampling was performed at seven stations, which differed in salinity, depth, and substrate. Three samples were taken at each station (the total sample square was $6 \mathrm{~cm}^{2}$ ). The samples were sieved through $40 \mu \mathrm{m}$ mesh. The grain-size analysis was performed in the Hydrochemical Laboratory of the Oceanographical Institute in Nha Trang, Vietnam. The sampling sites are presented in Fig. 1. Stations 1, 2, and 3 are affected by the river flow of the Kai River; therefore, the salinity there may vary from 28 to $34 \%$. The sediments are quite various and include different soft sediments: from coarse sands and shell bottoms to fine alluvia.

Literature data. The data from various publications were compiled to make a species list of harpacticoids for the South China Sea: [7, 15, 17, 35, 40, 56, 61, $62,63,65,69]$ and three reviews $[39,48,64]$. The species list for five adjacent areas was also compiled (Fig. 2). These areas include the Philippines (the seacoasts of the inner Malay Archipelago seas and the Pacific sea- 


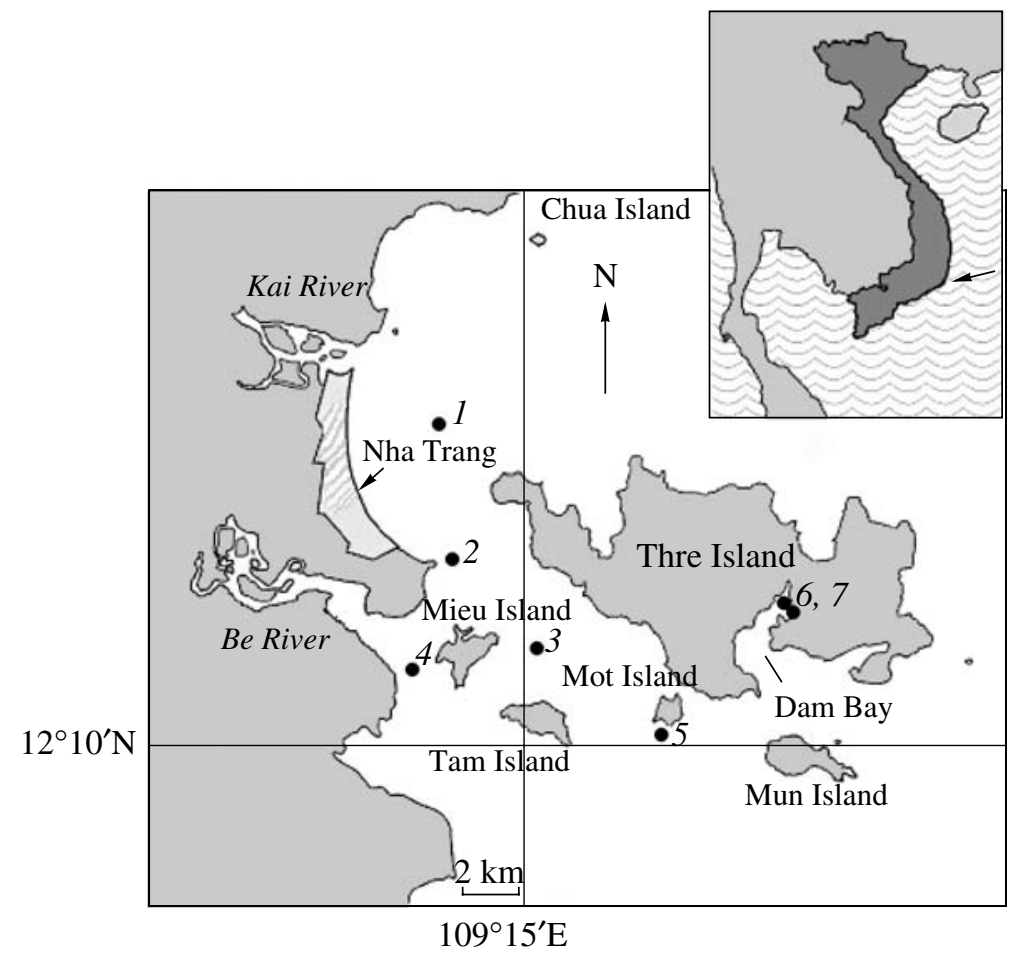

Fig. 1. The sampling area in the spring of 2004 in Nha Trang Bay. Stations 1-7.

coast); the Java, the Flores, the Sulawesi (Celebes), and the Banda seas; the New Guinea seacoast; the Yellow Sea (including the Kyushu and Ryukyu Islands); and the Andaman and Nicobar Islands. The list was created using many of $[9,10,14,16,18-31,33,34,38-48,50-55$, $58,59,60,67,68]$. The full reference list is too long to include in the present publication; therefore, only the most important publications are cited.

Taxonomy and life forms. The taxonomy system of European harpacticoids [13] was used for species list compilation. The unification of the synonymic species was performed using the Bodin catalogue [8].

The existing classification of harpacticoid life forms [3] was applied. The macrophytes-associated, planktonic, epibenthic, and facultative (or true intersticial) forms were distinguished under the ecological and morphological characteristics of the species and genuses.

The vertical zonal distribution of the harpacticoids was not taken into account when analyzing the fauna of different regions. The lack of data in the existing dataset does not allow the assured definition of littoral, sublittoral, and abyssal species complexes.

The taxocene definition. The Braun-Blanke method was applied for the taxocene definition with some modifications for marine benthic communities $[3,5]$. A certain species impact on the total species abundance was used as the primary data for the further recalcula- tions. Twenty four species were allocated with each having more than a $5 \%$ impact on the total abundance. Data diagonalization was applied, the differential species were defined, and matrix ordering with further taxocene definitions was performed.

Statistics. The pairwise similarity of the samples was evaluated using the Czekanowski index [2]:

$$
D_{X Y}=\sum_{i=1} \min \left(X_{i}, Y_{i}\right)
$$

where $X_{i}$ and $Y_{i}$ are the $i$-specific features for the $X$ and $Y$ characteristics.

The rate of ovelapping was recalculated for the comparison of the regional faunas. The rates of the specific and cosmopolitan species are defined for each area. The fauna similarity was evaluated using the Hacker-Dice index $(H)$ for the qualitative data [2]:

$$
H(x, y)=a /[a+\min (b, c)] ;
$$

where $a$ is the number of shared characteristics for the subjects $x$ and $y$; and $b, c$ are the number of unique characteristics. This index is insensitive to the negative coincidence of characteristics and is easy to use for comparing the faunas of different regions when each list contains a low number of species common to all of the areas. 


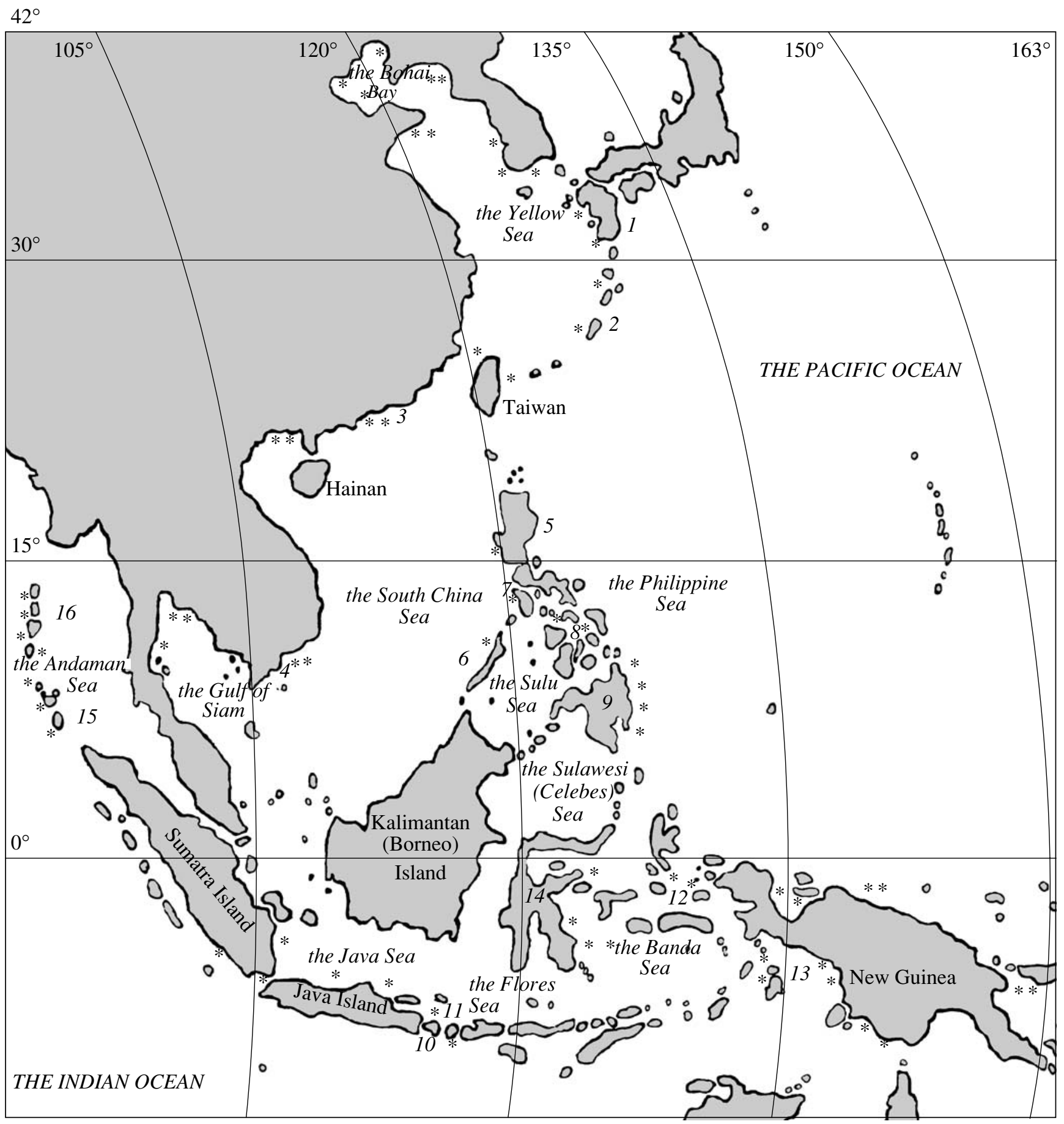

Fig. 2. The investigated sites (the asterisk number is the level of knowledge).

(1) the Kyushu Islands; (2) the Ryukyu Islands; (3) the Pearl River delta; (4) Nha Trang Bay; (5) Luzon Island; (6) Palawan Island; (7) Mindoro Island; (8) Cebu Island; (9) Mindanao Island; (10) Bali Island; (11) Lombok Island; (12) the Obi Islands; (13) the Aroe Islands; (14) Sulawesi (Celebes) Island; (15) the Nicobar Islands; (16) the Andaman Islands.

Additionally, the species/genus ratio was used. This ratio is affected both by the biodiversity and the level of knowledge for each region, as was described previously for the harpacticoid fauna of the seas of Russia [4]. The ratio is about 2 for the well-studied regions of the Black, Baltic, and Barents seas and less than 1.7 for the frontiers basins of the Azov, Caspian, Laptev, and Kara seas and some others. 


\section{RESULTS AND DISCUSSION}

The biodiversity and fauna specifics of the South China Sea. The compilation of the species lists was performed for the known Harpacticoida (Copepoda) fauna based on both original and literature data. The species location is given in brackets.

The AMEIRIDAE Family

Ameira sp. nov. Chappius, 1930 (seacoast of Guangdong Province, China)

Nitokra arctolongus Shen \& Tai, 1973 (seacoast of Guangdong Province, China)

Nitokra platypus bakeri Chappuis, 1930 (Gulf of Siam, Thailand; Luzon Island, the Philippines)

Nitokra cf. affinis Gurney, 1927 (Nha Trang Bay, Vietnam)

Nitokra sp. nov. (Nha Trang Bay, Vietnam)

Family ANCORABOLIDAE

Paralaophontodes elegans Baldari \& Cottarelli, 1986 (Mindoro Island, the Philippines)

Family CANTHOCAMPTIDAE

Heteropsyllus sp. (Nha Trang Bay, Vietnam)

Mesochra quadrispinosa Shen \& Tai, 1965 (the

Pearl River delta, Guangdong Province, China)

Mesochra prowaseki Van Domve, 1907 (seacoast of

Guangdong Province, China)

Mesochra cf. pygmaea (Claus, 1863) (Nha Trang

Bay, Vietnam)

Family CANUELLIDAE

Brianola elegans Hamond, 1973 (Nha Trang Bay, Vietnam)

Brianola sp. nov. (Nha Trang Bay, Vietnam)

Family CLETODIDAE

Cletocamptus affinis Kiefer, 1957 (seacoast of

Guangdong Province, China)

Cletodes sp. nov. (Nha Trang Bay, Vietnam)

Enhydrosoma sp. nov. (Nha Trang Bay, Vietnam)

Limnocletodes oblongatus Shen \& Tai, 1964 (the

Pearl River delta, Guangdong Province, China)

Limnocletodes angustodes Shen \& Tai, 1963 (the

Pearl River delta, Guangdong Province, China)

Schizacron bifurcarostratum (Shen \& Tai, 1965)

(the Pearl River delta, Guangdong Province, China)

Stylicletodes cf. reductus Wells, 1965 (Nha Trang

Bay, Vietnam)

Family DARCYTHOMPSONIIDAE

Leptocaris sp. nov. (Nha Trang Bay, Vietnam)

Family LONGIPEDIIDAE

Longipedia scotti Sars, 1903 (Nha Trang Bay, Vietnam)

Family MIRACIIDAE

Amphiascus sp. 1 nov. (Nha Trang Bay, Vietnam)

Amphiascus sp. 2 (Nha Trang Bay, Vietnam)

Amphiascus sp. 3 (Nha Trang Bay, Vietnam)

Amphiascoides sp. nov. (Nha Trang Bay, Vietnam)
Bulbamphiascus sp. (Nha Trang Bay, Vietnam)

Cladorostrata brevipoda Shen \& Tai, 1963 (Pearl

River delta, Guangdong Province, China)

Cladorostrata longipoda Shen \& Tai, 1963 (Pearl

River delta, Guangdong Province, China)

Diosaccus sp. (Nha Trang Bay, Vietnam)

Macrosetella gracilis (Dana, 1847) (in the plankton, the water area of the South China Sea)

Paramphiascella langi (Monard, 1936) (seacoast of Guangdong Province, China)

Paramphiascella sp. (seacoast of Guangdong Province, China)

Pararobertsonia sp. nov. (Nha Trang Bay, Vietnam)

Robertgurneya sp. 1 nov. (Nha Trang Bay, Vietnam)

Robertgurneya sp. 2 (Nha Trang Bay, Vietnam)

Robertsonia cf. knoxi (Thompson \& A. Scott, 1903)

(Nha Trang Bay, Vietnam)

Schizopera clandestina (Klie, 1924) (seacoast of

Guangdong Province, China)

Schizopera longirostris (Daday, 1901) (the Chao

Prai River delta, Thailand)

Stenhelia (D.) latioperculata Itô, 1981 (Nha Trang

Bay, Vietnam)

Stenhelia ornementalia Shen \& Tai, 1965 (the Pearl

River delta, Guangdong Province, China)

Stenchelia sp. nov. (Nha Trang Bay, Vietnam)

Family ECTINOSOMATIDAE

Ectinosoma sp. nov. (Nha Trang Bay, Vietnam)

Halectinosoma sp. nov, (Nha Trang Bay, Vietnam)

Microsetella rosea (Dana, 1848) (in the plankton, the Gulf of Siam)

Microsetella norvegica (Boeck, 1865) (the Pearl

River delta, Guangdong Province, China)

Hastigerella sp. nov. (Nha Trang Bay, Vietnam)

Pseudobradia sp. (Nha Trang Bay, Vietnam)

Family HUNTEMANNIIDAE

Huntemannia biarticulatus Shen \& Tai, 1973 (seacoast of Guangdong Province, China)

Nannopus unisegmentatus Shen \& Tai, 1964 (the Pearl River delta, Guangdong Province, China)

Family LAOPHONTIDAE

Apolethon bilobatus Shen \& Tai, 1973 (seacoast of

Guangdong Province, China)

Apolethon trigonus Shen \& Tai, 1973 (seacoast of

Guangdong Province, China)

Carcinocaris serrichelata Cottarelli, Bruno \& Bereira, 2006 (Mindoro Island, the Philippines)

Elapholaophonte decaceros Schizas \& Shirley, 1994 (Luzon Island, the Philippines)

Laophonte vitiospinulosa Shen \& Tai, 1963 (the Pearl River delta, Guangdong Province, China)

Onichocamptus mohammed (Blanchard \& Richard, 1891) (the estuaries of Thailand) 
Pararolaophonte sp. (Nha Trang Bay, Vietnam)

Quinquelaophonte quinquespinosa (Sewell, 1924) (Nha Trang Bay, Vietnam)

Xanthilaophonte trispinosa (Sewell, 1940) (Mindoro Island, the Philippines)

Family PARAMESOCHRIDAE

Apodopsyllus biarticulatus Cottarelli \& Altamura, 1986 (Palawan Island, the Philippines)

Scottopsyllus sp. nov. (Nha Trang Bay, Vietnam)

Paramesochra sp. nov. (Nha Trang Bay, Vietnam)

Family PARANANNOPIDAE

Sentiropsis sp. nov. (Nha Trang Bay, Vietnam)

Family PARASTENHELIIDAE

Parastenhelia sp. (Nha Trang Bay, Vietnam)

Family PELTIDIIDAE

Clytemnestra hendorffi quinquesetosa Huys \& Conroy-Dalton, 2000 (in the plankton, the Gulf of Siam)

Clytemnestra scutellata (Dana, 1848) (in the plankton, the water area of the South China Sea)

Eupelte acutispinis Zhang \& Li, 1976 (the Pearl River delta, Guangdong Province, China)

Family TACHIDIIDAE

Euterpina acutifrons (Dana, 1848) (in the plankton, the Gulf of Siam)

Microarthridion litospinatus Shen \& Tai, 1973 (Nha Trang Bay, Vietnam; seacoast of Guangdong Province, China)

Neotachidius triangularis Shen \& Tai, 1963 (the Pearl River delta, Guangdong Province, China)

Sinothachidius vicinospinalis (Shen \& Tai, 1964)

(the Pearl River delta, Guangdong Province, China)

Family TETRAGONICIPTIDAE nam)

Phyllopodopsyllus sp. nov. (Nha Trang Bay, Viet-

Diagoniceps sp. nov. (Nha Trang Bay, Vietnam)

Family THALESTRIDAE

Eudactylopus sp. nov. (Nha Trang Bay, Vietnam)

Diarthrodes nhatrangensis (Gómez, Chertoprud \& Morale-Serna, 2008) (Nha Trang Bay, Vietnam)

Diarthrodes savinkini (Gómez, Chertoprud \& Morale-Serna, 2008) (Nha Trang Bay, Vietnam)

Diarthrodes sp. nov. (Nha Trang Bay, Vietnam)

Family TISBIDAE

Zosime sp. (Nha Trang Bay, Vietnam)

Nowadays, seventy-seven Harpacticoida species are described for the South China Sea (57 genera and 19 families). Twenty-one species from this list are newly described (marked as "sp. nov."). Fifteen species were impossible to define by species and they are presented as genera (marked as "sp.").

The maximal species number was described for two families: Laophontidae (9) and Miraciidae (20). Meanwhile, the species/genus ratio for the South China Sea is quite low compared to the other well-studied seas and does not exceed 1.35. The same ratio for the Baltic, Barents, and Black seas (200, 144, and 262 harpacticoid species, respectively) varies from 2.01 to 2.55 [4].

The epibenthic species inhabiting the deposits of spring floods and the upper layers of soft sediments dominate $(61 \%)$ in the South China Sea. The fauna associated with macrophytes has an impact of only $4 \%$ compared to the values described in the temperate and polar seas. These species are represented by the families Peltidiidae (Eupelte acutispinis), Thalestridae (Eudactylopus sp. nov.), and Tisbidae (Zosime sp.). The lack of the studies, as well as the substitution of macrophytes by coral reefs [1], may be the main reason for such low values. True intersticial harpacticoids with the vermiform and lanceolar body shapes are represented by the following families constituting $7.8 \%$ of the total species number: Paramesochridae (Apodopsyllus biarticulatus, Scottopsyllus sp. nov., Paramesochra sp. nov.), Ectinosomatidae (Hastigerella sp. nov.), Darcythompsonidae (Leptocaris sp. nov.), and Laophontidae (Elapholaophonte decaceros). These forms are usually underestimated even in well-studied areas [4]. The major reason is the method specificity - the use of a 70-80 $\mu \mathrm{m}$ mesh size for the sample sieving leads to a nearly total loss of the small forms. We assume the application of other sieving methods will increase the number of intersticial species found for the South China Sea. The biodiversity of the facultative intersticial forms, which are mostly represented by unspecialized species, is much higher. They are represented by the following families: Ameiridae (Ameira sp. nov., Nitokra platypus bakeri, $N$. arctolongus, $N$. cf. affinis, Nitokra sp. nov.), Canthocamptidae (Mesochra quadrispinosa, M. prowaseki, M. cf. pygmaea), and Miraciidae (Amphiascus sp. 1 nov., sp. 2, sp. 3, Amphiascoides sp. nov., Bulbamphiascus sp.). These species constitute $16.9 \%$ of the total species biodiversity. Two commensal species (Carcinocaris serrichelata and Xanthilaophonte trispinosa, 2.6\%) are found in the branchial cavity of crabs (family Xanthidae) [17]. The planktonic species $(7.8 \%)$ are well studied. They include such species as Euterpina acutifrons, Clytemnestra hendorffi quinquesetosa, Clytemnestra scutellata, Microsetella rosea, Microsetella norvegica, and Macrosetella gracilis.

About 57\% of the species found in the South China Sea are not described for the other areas and may be defined as endemic ones. However, the study of the harpacticoid fauna in the tropical seas is just starting and the areas of the species are still to be defined; thus, the number of endemic species may decrease. The taxonomy of fourteen species newly found in Nha Trang Bay is still unclear, so their area could not be defined. The areas of eighteen species belong to the other areas, including the South China Sea.

(1) Tropical areal.

(A) Indo-Pacific group. Nitokra platypus bakeri was found on the southern seacoast of China and on the sea- 
coasts of Japan and the Philippines. Sinothachidius vicinospinalis was described for the southern seacoasts of China and Korea. Mesochra prowaseki and Clytemnestra hendorffi quinquesetosa are found in the South China Sea and in the seas of the Malay Archipelago. Stenhelia latioperculata is usual for the Sea of Japan. Brianola elegans and Schizopera longirostris were found on the New Guinea and Australian seacoasts and in the South China Sea. Xanthilaophonte trispinosa was described for the Phillipines and in the eastern part of the Indian Ocean.

(B) Wide-tropical (Circumtropical?) group. Paramphiascella langi is known from the Algerian and Chinese seacoasts. The areal of Quinquelaophonte quinquespinosa expands to the seacoasts of India, Australia, Indonesia, and Africa and even to the Mediterranean.

\section{(2) Cosmopolites.}

Longipedia scotti was described for the New Guinea and Andaman Islands seacoasts and in the South China Sea, as well as for all the European seacoasts. Schizopera clandestina is usual for the Malay Archipelago and the New Zealand seacoasts and also for the Atlantic and Mediterranean coasts of Europe and for Northern Africa. Onichocamptus mohammed was found in the South China Sea, on all the European seacoasts, on the Central and Northern African seacoasts, in the Caribbean Sea, and in Brazilian seawaters. Euterpina acutifrons, Clytemnestra scutellata, Microsetella rosea, and Macrosetella gracilis are usual for plankton sampled on the Australian seacoast, the Malay Archipelago, near India, near Europe, and near both Americas. Microsetella norvegica has a similar areal; however, it is rarely found in the Southern Hemisphere.

Taxocenes of soft sediments in Nha Trang Bay. Three taxocenes (associations) were described for seven stations (Table 1). Each taxocene is characterized by 1-2 species dominating by abundance. The long lists of sporadical species, which are usual for each association, have been compiled. This is the main reason why the average similarity of the species lists for each station united in one taxocene is quite low (the Czekanowski index (D) is $0.52 \pm 0.1)$. However, the similarity between all the stations is much lower $(\mathrm{D}=0.03 \pm 0.07)$. Therefore, the taxocenes were significantly allocated.

\section{Taxocene types}

(1) The taxocene Phyllopodopsyllus-Brianola (stations 6 and 7) was found for the upper and middle littoral in medium dirty sands (Dam Bay, Thre Island). The seacoast is characterized by mangroves (Rhizophora sp.). Two large epibenthic species are dominating there: Brianola sp. nov. and Phyllopodopsyllus sp. nov. (79.7\% by abundance). Other epibenthic species are less represented: Quinquelaophonte quinquespinosa (2.9\%), Nitokra sp. nov. (4\%), Stenhelia latioperculata $(2.8 \%)$, and Cletodes sp. nov. (8.3\%). The average harpacticoid abundance is 8.3 ind. $\mathrm{cm}^{-2}$. Eight species
Table 1. The Harpacticoida taxocene characteristics in Nha Trang Bay. The taxocenes were allocated using the BraunBlanke method. The species average fractions by abundance in the taxocene are presented

\begin{tabular}{l|c|c|c}
\hline Taxocene number & 1 & 2 & 3 \\
Number of stations & 2 & 2 & 3 \\
Average salinity, \%o & \multicolumn{1}{c|}{34} & $28-34$ & $28-34$ \\
Depth, m & $0-2$ & $13-17$ & $10-22$ \\
Modal particle size, mm & $0.06-0.25$ & $0.25-1$ & $0.02-0.06$ \\
$\begin{array}{l}\text { Most abundant weight } \\
\text { fraction, \% }\end{array}$ & 30.1 & 36.8 & 45.1 \\
$\begin{array}{l}\text { Aleuropelite weight } \\
\text { fraction, \% }\end{array}$ & 18 & 3.5 & 77.2 \\
\end{tabular}
Harpacticoida species

\begin{tabular}{l|c|c|c} 
Brianola sp. nov. & 24.3 & 0 & 0 \\
Brianola elegans & 0 & 10.0 & 1.7 \\
Longipedia scotti & 0 & 5.2 & 0 \\
Quinquelaophonte & 2.9 & 0 & 0 \\
quinquespinosa & & & \\
Phyllopodopsyllus sp. nov. & 55.4 & 0 & 0 \\
Nitokra cf. affinis & 0 & 1.5 & 1.7 \\
Nitocra sp. nov. & 4.0 & 0 & 0 \\
Ameira sp. nov. & 0 & 7.5 & 0 \\
Stenhelia latioperculata & 2.8 & 6.5 & 0 \\
Amphiascus sp. 1 nov. & 0 & 4.8 & 0 \\
Amphiascus sp. 2 & 0 & 2.9 & 0 \\
Amphiascus sp. 3 & 0 & 2.5 & 0 \\
Amphiascoides sp. nov. & 0 & 42.0 & 0 \\
Bulbamphiascus sp. & 0 & 1.8 & 0 \\
Robertgurneya sp. 1 nov. & 0 & 2.9 & 0 \\
Pararobertsonia sp. nov. & 0 & 0 & 4.4 \\
Zosime sp. & 0 & 0 & 3.6 \\
Sentiropsis sp. nov. & 0 & 4.8 & 2.5 \\
Stylicletodes cf. reductus & 0 & 0 & 3.6 \\
Cletodes sp. nov. & 8.3 & 0 & 0 \\
Halectinosoma sp. nov. & 0 & 1.9 & 16.7 \\
Diarthrodes savinkini & 0 & 0 & 30.6 \\
Diarthrodes nhatrangensis & 0 & 0 & 28.6 \\
Microarthridion litospinatus & 0 & 0 & 1.7 \\
\hline
\end{tabular}

were defined. The average similarity (D) for the stations is $0.62 \pm 0.13$.

(2) The taxocene Amphiascoides (stations 1 and 5) is usual for sublittoral washed sandstone grits (depths of 13-17 m). It was found for the southern seacoast of Mot Island and the inlet in between the Kai River delta and Thre Island. The small unspecific intersticial species Amphiascoides sp. nov. is dominating in all the samples ( $42 \%$ by abundance). A long list of numerically insignificant species $(21 \%$ by abundance in total) was also compiled. They include the epibenthic species Brianola elegans (10\%), Longipedia scotti (5.2\%), Stenhelia latio- 
perculata (6.5\%), Robertgurneya sp. nov. 1 (2.9\%), and Sentiropsis sp. nov. (4.8\%); the mud-burrower species Halectinosoma sp. nov. (1.9\%); and an unspecific intersticial species complex (Nitokra cf. affinis, Ameira sp. nov., (Amphiascus sp. 1 nov., sp. 2, sp. 3, Bulbamphiascus sp.). The average harpacticoid abundance is 17.9 ind. $\mathrm{cm}^{-2}$. The average similarity (D) for the stations is $0.50 \pm 0.14$.

(3) The taxocene Diarthrodes (stations 2, 3, and 4) inhabits sublittoral fine muddy sands and shell bottoms in (depths of 10-22 m) between the islands of Mieu and Thre. Diarthrodes nhatrangensis and D. savinkini are the most abundant species (59.2\% by abundance). The minor species complex includes the epibenthic species Brianola sp. nov. (1.7\%), Pararobertsonia sp. nov. (4.4\%), Zosime sp. (3.6\%), Sentiropsis sp. nov. (2.5\%), Microarthridion litospinalis (1.7\%), and Slylicletodes cf. reductus (3.6\%); the mud-burrower species Halectinosoma sp. nov. (16.7\%); and the unspecific intersticial species Nitokra cf. affinis (1.7\%). The average harpacticoid abundance is 1.7 ind. $\mathrm{cm}^{-2}$. Eighteen species were defined. The average similarity (D) for the stations is $0.42 \pm 0.1$ due to the low total abundance and high species biodiversity.

The sediment type plays a principal role in the harpacticoid taxocene development in the sublittoral zone. The depth also plays a significant role in the species biodiversity and abundance. The average abundance, as well as the number of species, decreases when the depth is more than $15 \mathrm{~m}$. Samples without any harpacticoids are frequent for muddy sediments at depths of $20 \mathrm{~m}$ (taxocene 3). The samples obtained from the coarse sands are enriched in their species abundance (35.4 ind $\mathrm{cm}^{-2}$ on average) compared to the muddy sediments (3.1 ind $\mathrm{cm}^{-2}$ on average) at the same depths and of the same salinity. The same tendency was described for the White Sea [3].

\section{Comparative Analysis of the Fauna}

The comparative analysis of the harpacticoids fauna has been performed for different areas, including the South China Sea; the Philippines; the seacoasts of the inner Malay Archipelago seas; the Java, the Flores, the Sulawesi (Celebes), and the Banda seas; the New Guinea seacoast; the Yellow Sea; and the Andaman and Nicobar Islands. Our knowledge of each region varies greatly. Only the fauna of the Andaman and Nicobar Islands is well-studied; it includes $40-50$ publications. Less information is available about the New Guinea seacoast and the Yellow Sea fauna (20-30 publications). Even though the number of publications for the South China Sea is similar to the previous two areas, the knowledge about this region is quite low, since more than one- third of the species list is not described yet. Short species lists were compiled for vast regions of the Philippines and of the Java, the Flores, the Sulawesi (Celebes), and the Banda seas. The knowledge of the harpacticoids in the last areas was obtained during several research cruises; thus, we expect the information to increase in the future.

The species biodiversity for certain life forms is quite various for different areas. However, the real biodiversity differences are not the only main reason, other factors such as the variation of the methods applied and the authors' priorities are important (when much attention is paid only to the genera of the harpacticoids) [17, 47].

True intersticial species. The species expansion is quite heterogenic; sixteen species are found for the Andaman and Nicobar Islands. Meanwhile, they are absent for the seacoasts of the inner Malay Archipelago seas and the Yellow Sea. The maximal species impact was found only for one area out of the six investigated in the Indo-Pacific ( $91 \%$ by biodiversity).

Facultative intersticial species. The maximal species number was described for the South China Sea and the islands of the Indian Ocean (12-13 species). The species impact on the total biodiversity varies greatly from $6.7 \%$ (the Philippines and the New Guinea seacoast) to $16.9 \%$ (the South China Sea). The species-specific impact is lower compared to the previous group (85\%).

Macrophytes-associated species. The number of species of this group varies for different areas. They are absent for the Philippines and constitute one-third of the total biodiversity in the Yellow Sea. The Bohai Sea (the northern part of the Yellow Sea) is situated in temperate waters; thus, the coral reefs there are substituted for by macrophytes. This is the main reason for the peak of the macrophytes-associated species here. Both Korean and Chinese taxonomists are working in this region, and they have already described more that 10 endemic species of the Porcellidiidae, Peltidiidae, and Thalestridae families. It is no wonder that here the species-specific impact is quite high compared to the other regions $(88 \%)$.

Epibenthic species. The epibenthic species constitute from $50 \%$ to $80 \%$ in all the studied areas; $89 \%$ of them are area-specific. The species similarity (D) is low and is about $0.07 \pm 0.07$. The Philippines is the most outstanding area, where more than one-third of the species list belongs to the exotic family of Aegisthidae inhabiting the low sublittoral and abyssal zones. The reason for such a phenomenon is the giant descriptive work performed by the Japanese taxonomist Ito in the late XXth century for Mindanao Island [44, 45]. These species are endemics of the Philippines with high probability. The isolation of the oceanic trenches may affect the speciation among the meiobenthic forms [66].

Planktonic species. The species list is quite similar for all the areas. All the water areas include a complex of four cosmopolite species: Macrosetella gracilis, Microsetella rosea, Clytemnestra scutellata, and Euterpina acutifrons. The species similarity (D) is the highest $(0.91 \pm 0.14)$.

Altogether, more than four hundred harpacticoid species (Table 2) are described for the studied area, 
Table 2. The taxonomic characteristics of the Harpacticoida fauna for different areas of the Indo-Pacific

\begin{tabular}{|c|c|c|c|c|c|}
\hline Area & $\begin{array}{l}\text { Number } \\
\text { of species }\end{array}$ & $\begin{array}{l}\text { Species specific } \\
\text { for the area }(\%)\end{array}$ & $\begin{array}{l}\text { Number } \\
\text { of genera }\end{array}$ & $\begin{array}{l}\text { Genera specific } \\
\text { for the area }(\%)\end{array}$ & $\begin{array}{l}\text { Spe- } \\
\text { cies/Genus } \\
\text { ratio }\end{array}$ \\
\hline The South China Sea & 77 & $48(62.3 \%)$ & 57 & $20(35.7 \%)$ & 1.35 \\
\hline The Philippines & 30 & $24(83.3 \%)$ & 20 & $13(65.0 \%)$ & 1.50 \\
\hline $\begin{array}{l}\text { The seas of the Malay Archipelago (the Java Sea, } \\
\text { the Flores Sea, the Banda Sea, and the Sulawesi } \\
\text { (Celebes) Sea) }\end{array}$ & 41 & $22(53.7 \%)$ & 30 & $4(13.3 \%)$ & 1.37 \\
\hline New Guinea & 65 & $37(56.9 \%)$ & 48 & $13(27.1 \%)$ & 1.35 \\
\hline The Andaman and Nicobar Islands & 184 & $155(84.7 \%)$ & 95 & $32(33.7 \%)$ & 1.94 \\
\hline The Yellow Sea & 70 & $59(84.3 \%)$ & 46 & $16(34.7 \%)$ & 1.52 \\
\hline Total & 402 & $345(86 \%)$ & 170 & $98(57.6 \%)$ & 2.37 \\
\hline
\end{tabular}

constituting a large part of the Indo-Pacific and characterized by the possibility of high biodiversity [6]. However, only one region among the six studied is characterized by a high percentage of area-specific species ( $86 \%$, or 345 species). For certain seas or sea complexes, the area-specific species impact varies from $53.7 \%$ (the Java, the Flores, the Sulawesi (Celebes), and the Banda seas) to $84.7 \%$ (the Andaman and Nicobar Islands) (Table 2). Only $46 \%$ of the species from the total list are found in 2-4 regions. Twenty-nine of them are cosmopolites and seventeen are described only for the tropics.

Obviously, the average similarity of the area-specific species lists is extremely low; the Hacker-Dice index is $0.15 \pm 0.08$. The most studied faunas of New Guinea and the Andaman and Nicobar Islands have the highest index ratio of 0.28 ; the less studied fauna of the seacoasts of the inner Malay Archipelago seas is quite similar to the two previous.

There is still a question about the reason for the low similarity of the harpacticoid tropical fauna in different areas of the Indo-Pacific. The compared seas are situated in the same climatic province (except the Yellow Sea), and their water areas are closely connected with each other both by wide straits and monsoon-trade wind currents. The high probability of water exchange may be the main reason for the possible similarity of the harpacticoid fauna in all the Indo-Pacific. Many of the benthic harpacticoids may "migrate" by means of bottom water currents or with kelp, thus drifting for tens or even hundreds of kilometers [36]. Obviously, the low fauna similarity is due to another reason than area isolation. The fauna similarity of the Barents and the White seas, which are connected by a wide strait, is about 0.73 (the Hacker-Dice index) [4]. This is more than seven times higher compared to the similarity of the South China Sea and the Philippines; the HackerDice index is 0.1. Probably, the major reason such low similarity is the poor knowledge of the harpacticoid fauna and its distributional patterns. The low species/genus ratio is the other evidence (Table 2). Besides, the species number in the well-studied North Sea and the Mediterranean, whose areas are ten times less compared to the inner Malay Archipelago seas, is about 700 and 500, respectively [32]. The number of publications about these well-studied areas is about one thousand; in the meantime, only two hundred publications exist for this sector of the Indo-Pacific. As an example, about $60 \%$ of the species in the Java, Sulawesi (Celebes), and Banda seas and the adjacent Malay Archipelago seas are described by only the samples taken during Scott's expedition in 1899-1900 [57].

The complex analysis of the faunas for various climatic provinces exhibits the increasing of the harpacticoid species number in the meridian direction from the Arctic to the temperate and subtropical waters $[37,66]$. The tropic fauna is considered to be the most diverse [6, 48]. We agree with Lang's expression that "...the present knowledge of the tropical fauna is the only the tip of the iceberg, which will crush the "Titanic" of the up-to-date taxonomy" [48].

\section{ACKNOWLEDGMENTS}

The authors are grateful to Professor T.A. Britaev and Dr. A.A. Udalov (Russian-Vietnamese Scientific and Technical Center, Far East Branch) for the samples presented.

The present study was financed by the Russian Foundation for Basic Research (project no. 09-0401151).

\section{REFERENCES}

1. N. G. Vinogradova, "Fauna of the Shelf, Continental Slop, and Abyssal Zone," in Biological Structure of the Ocean (Nauka, Moscow, 1977), Vol. 1, pp. 178-198 [in Russian]. 
2. V. Yu. Urbakh, Statistical Analysis in Biological and Medical Studies (Meditsina, Moscow, 1975) [in Russian].

3. E. S. Chertoprud, M. V. Chertoprud, D. V. Kondar', et al., "Taxocen Diversity of Harpacticoids (Copepoda) in the Sandy-Silty Intertidal Zone of Kandalaksha Bay of the White Sea," Okeanologiya 46 (4), 10-19 (2006) [Oceanology 46 (4), 1-10 ].

4. E. S. Chertoprud and L. A. Garlitskaya, "A Comparative Analysis of the Harpacticoida (Copepoda) Faunas from the Northern and Southern Seas of Russia,' Okeanologiya 47 (6), 1-10 (2007) [Oceanology 47 (6), 814-824 (2007)].

5. M. V. Chertoprud, A. A. Udalov, A. P. Stolyarov, and R. R. Borisov, "Diversity of Macrobenthic Communities in the White Sea Estuaries," Okeanologiya 44 (6), 901911 (2004) [Oceanology 44 (6), 845-855 (2004)].

6. L. G. Abele, The Biology of Crustacea, Ed. by D. E. Bliss (London, Academic Press, 1982), vol. 1, pp. 242-304.

7. F. Baldari and V. Cottarelli, "A New Species of the Genus Paralaophontodes (Crustacea: Copepoda: Harpacticoida) from Interstitial Waters of Mindoro Island (The Philippines)," Publ. Seto mar. Lab 31 (3/6), 163168 (1986).

8. P. Bodin, "Catalogue of the New Marine Harpacticoid Copepods (1997 Edition)," Documents de travail de l'Institut royale des Scieces naturelles de Belgique 89 , 1-304 (1997).

9. C. Y. Chang and H. S. Kim, "Harpacticella itoi, a New Harpacticoid Species from Korea (Copepoda: Harpacticoida: Harpacticidae)," Korean J. Syst. Zool. 7 (1), $73-$ 80 (1991).

10. C. Y. Chang and S. J. Song, "Marine Harpacticoid Copepods of Genus Eudactylopus (Harpacticoida, Thalestridae) in Korea," Korean J. Syst. Zool 11 (3), 379-388 (1995).

11. Q. C. Chen, Zooplancton of China Seas (Science Press, Beijing, 1992), Vol. 1, pp. 1-83.

12. Q. C. Chen, S. Z. Zhang, and S. Z. Zhu, "On Planctonic Copepods of the Yellow Sea and the East China Sea. II. Cyclopoida and Harpacticoida," Studia Mar. Sinica 9, 27-76 (1974).

13. European Register of Marine Species: A Check-List of the Marine Species in Europe and a Bibliography of Guides to Their Identification. Collection Patrimoines Naturels, Ed. by M. J. Costello, C. Emblow, and R. White (Muséum national d'Histoire Naturelle, Paris, 2001), Vol. 50, pp. 1-463.

14. V. Cottarelli, "Laophontidae Di Acque Interstiziali Litorali Dell'Indonesia,' Boll. Mus. Civ. St. Nat. Verona 12, 283-297 (1986).

15. V. Cottarelli and S. Altamura, "Una Nuova Specie Di Apodopsyllus (Crustacea, Copepoda, Harpacticoida) Di Acque Interstiziali Litorali Delle Filippine: Apodopsyllus biarticulatus n. sp.," Boll. Mus. Civ. St. Nat. Verona 12, 299-305 (1986).

16. V. Cottarelli and G. Mura, "Remarks on the Genus Afrolaophonte (Crustacea, Copepoda, Harpacticoida) and
Description of Three New Species," Vie Milieu 31 (2), 153-161 (1982).

17. V. Cottarelli, M. C. Bruno, and R. Berera, "Description of Carcinocaris serrihelata, gen. nov. sp. nov., Associated with Xanthid Crabs and New Data on the Distribution of Xanthilaophonte trispinosa (Copepoda: Harpacticoida)," Vie Milieu 56 (3), 1-11 (2006).

18. V. Cottarelli, A. C. Puccetti, and P. E. Saporito, "Osservazioni Sul Genere Psammopsyllus (Copepoda, Harpacticoida, Cylindropsyllidae) e Descrizione Di Tre Nuove Specie," Boll. Mus. Civ. St. Nat. Verona 11, 1-29 (1986a).

19. V. Cottarelli, A. C. Puccetti, and P. E. Saporito, "Indolaophonte ramai n. gen. n. sp. (Crustacea, Copepoda, Harpacticoida) Di Acque Interstiziali Litorali Dell'Isola Di Bali (Indonesia)," Boll. Mus. Civ. St. Nat. Verona 12, 273-281 (1986b).

20. F. Fiers, "New Canuellidae from the Northern Coast of Papua New Guinea (Copepoda: Harpacticoida)," Bull. Inst. Sci. Nat. Belg. 54 (4), 1-32 (1982).

21. F. Fiers, "A New Record of Ellucana longicauda Sewell, with the Description of the Male (Copepoda: Harpacticoida: Canuellidae)," Indo-Malayan Zool. 2, 177-185 (1984a).

22. F. Fiers, "Harpacticoid Copepods from the West Indian Islands: Canuellidae and Longipediidae (Copepoda, Harpacticoida)," Bijdr. Dierk. 54 (2), 197-210 (1984b).

23. F. Fiers, "Feregastes wellensi n. gen., n. sp., a New Genus of the Family Tegastidae (Copepoda, Harpacticoida) from the Andaman Islands," Crustaceana 51 (3), 277-285 (1986a).

24. F. Fiers, "Harpacticoid Copepods from the West Indian Islands: Laophontidae (Copepoda, Harpacticoida)," Bijdr. Dierk. 56 (1), 132-164 (1986b).

25. F. Fiers, "Harpacticoid Copepods from the West Indian Islands: Darcythompsoniidae (Copepoda, Harpacticoida)," Bijdr. Dierk. 56 (2), 282-290 (1986c).

26. F. Fiers, "New and Interesting Copepods (Crustacea, Copepoda) from Brackish Waters of Laing Island (Northern Papua, New Guinea)," Bull. Inst. Sci. Nat. Belg. 56, 99-120 (1986d).

27. F. Fiers, "Enhydrosoma Vervoorti Spec. Nov., a New Harpacticoid Copepod from India (Harpacticoida: Cletodidae)," Zool. Med., Leiden 61 (20), 295-302 (1987a).

28. F. Fiers, "Intercletodes interita n. gen., n. sp. and Orthopsyllus coralliophilus n. sp., Two New Copepods from the Northern Coast of Papua New Guinea (Copepoda, Harpacticoida)," Bull. Inst. Sci. Nat. Belg., Biol. 57, 123-132 (1987b).

29. F. Fiers, "Probosciphontodes n. gen., a New Genus of the Family Ancorabolidae, with the Description of Two New Species (Copepoda, Harpacticoida),' Bull. Inst. Sci. Nat. Belg., Biol. 58, 75-83 (1988).

30. F. Fiers, "Metis reducta $\mathrm{n}$. sp. and Laubieria tercera $\mathrm{n}$. sp. (Harpacticoida, Metidae) from the Southern Coast of Papua, New-Guinea," Belg. J. Zool. 122 (1), 37-51 (1992). 
31. F. Fiers, "The Laophontid Genus Loureirophonte Jakobi, 1953 (Copepoda, Harpacticoida)," Zool. Med. Leiden 67 (14), 207-238 (1993).

32. L. A. Garlitskaya, A.S. Chertoprud, D. V. Kondar', A. I. Azovsky. "Large-Scale Patterns in Harpacticoid Copepod Diversity and Distribution," Abstract of the World Conference on Marine Biodiversity, (2008), p. 54.

33. J. M. Gee and F. H. Mu, "A New Genus of Cletodidae (Copepoda; Harpacticoida) from the Bohai Sea, China," J. Nat. Hist. 34 (6), 809-822 (2000).

34. H. Gheerardyn, F. Fiers, M. Vincx, and M. De Troch, "Peltidiphonte gen. n., a New Taxon of Laophontidae (Copepoda, Harpacticoida) from Coral Substrates of the Indo-West Pacific Ocean," Hydrobiologia 553, 171-199 (2006).

35. S. Gómez, E. S. Chertoprud, and F. N. Morale-Serna, "On Some Diarthrodes Thomson, 1882 from Vietnam and North-Western Mexico," Cah. Biol. Mar. (2008), in press.

36. R. Hauspie and P. H. Polk, "Swimming Behaviour Patterns in Certain Benthic Harpacticoids (Copepoda)," Mar. Biol. Ass. 76, 95-103 (1974).

37. G. R. F. Hicks and B. C. Coull, "The Ecology of Marine Meiobenthic Copepod," Ann Rev. 21, 67-175 (1983).

38. J. Ho and J. Hong, "Harpacticoid Copepods (Thalestridae) Infesting the Cultivated Wakame (Brown Alga, Undaria pinnatifida) in Korea," J. Nat. Hist. Lond. 22, 1623-1637 (1988).

39. R. Huys (comp.) Harpacticoida. In: Copepod web portal. Internet pdf. Ed. Apr. 2007. http://www.copepods.interfree.it.

40. R. Huys and S. Conroy-Dalton, "Generic Concepts in the Clytemnestridae (Copepoda: Harpacticoida): Revision and Revival," Bull. Nat. Hist. Mus. Zool. 66, 1-48 (2000).

41. R. Huys, S. Ohtsuka, S. Conroy-Dalton, and Y. Kikuchi, "Description of Two New Species of Neotachidius Shen and Tai, 1963 (Copepoda, Harpacticoida, Tachidiidae) from Korean Brackish Waters and Proposal of a New Genus for Tachidius (Tachidius) Vicinospinalis Shen and Tai, 1964,” Zool. J. Linn. Soc. 143 (1), 133-159 (2005).

42. T. Itô, "Three Species of Marine Harpacticoid Copepods from Amakusa, Kyushu,” J. Fac. Sci. Hokkaido Univ. 18 (4), 516-531 (1973).

43. T. Itô, "New Species of Marine Harpacticoid Copepods of the Genera Harpacticella and Tigriopus from the Bonin Islands, with Reference to the Morphology of Copepodid Stages," J. Fac. Sci. Hokkaido Univ. 21 (1), 61-91 (1977).

44. T. Itô, "Harpacticoid Copepods from the Pacific Abyssal Off Mindanao. I. Cerviniidae," J. Fac. Sci. Hokkaido Univ? 23 (1), 63-127 (1982).

45. T. Itô, "Harpacticoid Copepods from the Pacific Abyssal Off Mindanao. II. Cerviniidae (Cont.), Thalestridae, and Ameiridae," Seto Mar. Biol. Lab? 28 (1/4), 151-254 (1983).

46. S. H. Kim and V. Kim, "Alteuthoides affinis, a New Peltidiid Copepod (Harpacticoida) Associated with the Sponge from Cheju Island, Korea," Korean J. Biol. Sci. 2 (2), 203-208 (1998).
47. "Harpacticoida," in Endemic Species of Korea, Ed. by S. H. Kim and V. Kim (Seul, 2005), Vol. 2, 44-47.

48. K. Lang, Monographie der Harpacticiden (Stocholm, 1948), Vols. 1, 2.

49. S. M. Long and O. B. H. Ross, "Vertical Distribution of Nematodes (Nematoda) and Harpacticoid Copepods (Copepoda: Harpacticoida) in Muddy and Sandy Bottom of Intertidal Zone at Lok Kawi, Sabah, Malaysia," Raff. Bull. Zool. 47, 349-363 (1999).

50. Y. Miura, "Subterranean Harpacticoid Copepods of the Amami Group of the Ryukyu Islands," Annot. Zool. Jap. 35 (2), 95-105 (1962).

51. F. H. Mu and R. Huys, "New Species of Stenhelia (Copepoda, Harpacticoida, Diosaccidae) from the Bohai Sea (China) with Notes on Subgeneric Division and Phylogenetic Relationships," Cah. Biol. Mar. 43 (2), 179206 (2002).

52. F. D. Por, "A Study of the Levantine and Pontic Harpacticoida (Copepoda Crustacea)," Zool. Verh. Leiden 64, 1-128 (1964).

53. C. G. Rao, "Littoral Meiofauna of Little Andaman," Rec. Zool. Surv. India. Occ. Paper 155, 1-120 (1993).

54. C. G. Rao and P. N. Gapati, "Some New Interstitial Copepods from Waltair Coast," Proc. Indian Acad. Sci. 69B, 1-14 (1969a).

55. C. G. Rao and P. N. Gapati, "On Some Interstitial Copepods from the Beach Sands of Waltair Coast," Proc. Indian Acad. Sci. 69B, 262-286 (1969b).

56. N. V. Schizas and T. C. Shirley, "Elapholaophonte decaceros n. gen., n. sp. (Copepoda: Harpacticoida, Laophontidae) from the Philippines," Trans. Am. Microsc. Soc. 113 (2), 127-141 (1994).

57. A. Scott, "The Copepoda of the Siboga-Expedition," in Siboga Exped. Monograph, Part I: Free-Swimming, Littoral and Semi-Parasitic Copepoda (1909), vol. 29a, pp. 1-323.

58. S. Seifried, "Three New Species of Ectinosoma Boeck, 1865 (Harpacticoida, Ectinosomatidae) from Papua New Guinea and the Fiji Islands," Microfauna Mar. 11, 35-58 (1997).

59. R. B. S. Sewell, "Copepoda Harpacticoida," in John Murray Exped. 1933-1934 (British Mus. (Nat. Hist.), 1940), vol. 7, No. 2, pp. 117-382.

60. C. J. Shen and S. O. Bai, "The Marine Copepoda from the Spawning Ground of Pneumatophorus japonicus (Houttuyn) Off Chefoo, China," Acta Zool. Sinica 8, 177-234 (1956).

61. C. J. Shen and A. Y. Tai, "On Five New Species, a New Subgenus and a New Genus of Freshwater Copepoda (Harpacticoida) from the Delta of the Pearl River, South China," Acta Zool. Sinica 15 (3), 417-432 (1963).

62. C. J. Shen and A. Y. Tai, "Descriptions of New Species of Fresh Water Copepoda from Kwangtung Province, South China," Acta Zootax. Sinica 1 (2), 367-396 (1964).

63. C. J. Shen and A. Y. Tai, "Descriptions of Six New Species of Freshwater Copepods Chiefly from the Pearl 
River Delta, South China,” Acta Zootax. Sinica 2 (2), 126-140 (1965).

64. C. J. Shen and A. Y. Tai, "Preliminary Analysis of the Characteristics of the Harpacticoid Copepod Fauna of China and Description of Some New Species," Acta Zool. Sinica 19 (4), 365-384 (1973).

65. L. C. Tseng, H. U. Dahms, Q. C. Chen, and J. S. Hwang, "Copepod Assemblages of the Northern South China Sea," Crustaceana 81 (1), 1-22 (2008).

66. J. B. J. Wells, "Biogeography of Benthic Harpacticoid Copepods of the Marine Littoral and Continental Shelf," Syllogeus 58, 126-135 (1986).
67. J. B. J. Wells, H. Kunz, and G. C. Rao, "A Review of the Mechanisms for Movement of the Caudal Furca in the Family Paramesochridae (Copepoda Harpacticoida), with a Description of a New Species of Kliopsyllus Kunz.," Mikrofauna Meeresboden 53, 1-16 (1975).

68. J. B. J. Wells and G. C. Rao, "Littoral Harpacticoida (Crustacea: Copepoda) from Andaman and Nicobar Islands," Mem. Zool. Surv. India 16 (4), 1-385 (1987).

69. C. Zhang and Z. Li, "Harpacticoida (Copepoda, Crustacea) from Xisha Islands of Guangdong Province, China," Acta Zool. Sinica 22, 66-70 (1976). 